\title{
Histology of Tritia mutabilis gonads: using reproductive biology to support sustainable fishery management
}

\author{
Alicia Mallet ${ }^{1, *}$, Jean-Yves Jouvenel ${ }^{1}$, Morgane Broyon ${ }^{2,3}$, Nelly Pirot $^{2,3}$ and Benjamin Geffroy ${ }^{4}$ \\ ${ }^{1}$ P2A developpement, 87 Avenue Ferdinand de Lesseps, Impasse Algrin, 34110 Frontignan, France \\ 2 BCM, Univ. Montpellier, CNRS, INSERM, Montpellier, France \\ 3 IRCM, Univ. Montpellier, ICM, INSERM, Montpellier, France \\ ${ }^{4}$ MARBEC, Univ Montpellier, Ifremer, IRD, CNRS, Palavas Les Flots, France
}

Received 20 October 2020 / Accepted 2 March 2021

Handling Editor: Ellen Kenchington

\begin{abstract}
The mutable nassa, Tritia mutabilis, a marine gastropod that is widely exploited on the Adriatic coast is an important source of income for small-scale fishermen in the Mediterranean Sea, particularly in the Gulf of Lion. However, the lack of knowledge on the ecology and biology of this species limits our capacities to propose and produce an effective management plan. As a result, stocks are currently declining, especially in Italy. In order to optimize a management plan for this fishery, we designed a study to better characterize the reproductive biology of T. mutabilis, using gonad histology and performing a regular monitoring of population size frequency. The average shell height of individuals during the breeding period was $24 \pm 2.7 \mathrm{~mm}$ for males and $30 \pm 3.7 \mathrm{~mm}$ for females. The presence of small females $(10 \mathrm{~mm})$ and large males $(32 \mathrm{~mm})$ in the whole sample challenged previous assumptions regarding protandry (sex change from male to female). The size at first maturity was estimated for males and females at $17.5 \mathrm{~mm}$ and $24.4 \mathrm{~mm}$ shell height, respectively. In Italy, current management measures include a minimum conservation reference size of $20 \mathrm{~mm}$ in shell height. Therefore, it is likely that many individuals that did not reproduce are being caught, which could partly explain the decline observed, despite conservation measures introduced more than ten years ago. Overall, our study provides some baseline information to establish, in consultation with fishermen, management measures for this small-scale fishery in France.
\end{abstract}

Keywords: Tritia mutabilis / gonad histology / gonochoric species / size at first maturity / fisheries management

\section{Introduction}

Marine molluscs are among the most important invertebrate fisheries, and gastropods represent about $2 \%$ of marine molluscs fished worldwide (Leiva and Castilla, 2002). Some species are highly valued in international markets and play important social roles in small-scale fisheries. The mutable nassa (Tritia mutabilis, Linnaeus, 1758) represents an important source of local income for small-scale fisheries in the central and northern Adriatic Sea. Fishermen collect this shellfish from the beginning of autumn to the end of spring, using baskets traps baited with dead fish. In Italy, the resource conservation measures recommend a minimum conservation reference size (MCRS $=20 \mathrm{~mm}$ in shell height), a daily quota

*Corresponding author: mallet@p2adev.com ranging from 100 to $180 \mathrm{~kg}$ depending on the vessel overall length, and a fishing season from early fall to late spring (Regulation 854/2004/EC (EUROPEAN COMMISSION, 2004). Despite all these measures, a constant decline in Italy has been observed in the last years (Grati et al., 2010), mainly due to the lack of knowledge on reproductive biology of the species. Since 2011, mutable nassa is actively fished in France, in the Gulf of Lion area. A better understanding on the reproductive biology of the species would be the cornerstone for the development of a resource management plan. Tritia mutabilis lives in the first layer $(<5 \mathrm{~cm})$ of sandy-muddy bottoms in the neritic zone (they are found between 2 and $15 \mathrm{~m}$ deep off the Mediterranean coasts, Fisher et al., 1987). The spawning season occurs in late winter, early spring (Polidori et al., 2015). Females lay eggs in transparent capsules which they deposit on a hard substrate (Fabi and Giannini, 1983). After the larval stage, individuals spend much of their time 


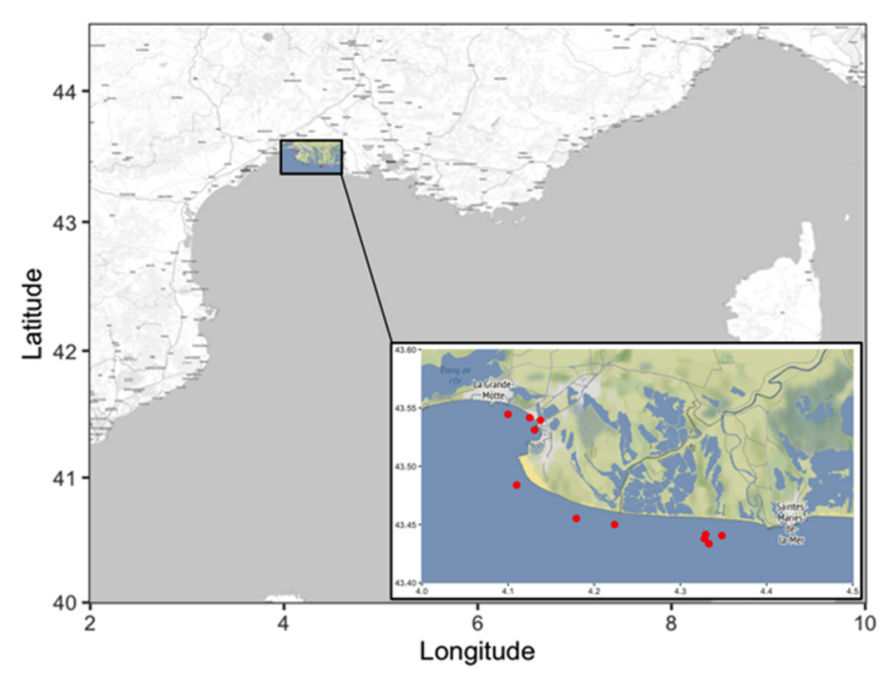

Fig. 1. Sampling area in the Grau du Roi site in the Gulf of Lion.

buried in the sediment. At adulthood, the largest individuals, mainly females, can reach $40 \mathrm{~mm}$. Knowledge on the species reproductive biology is still very limited. Based on biometric analyses, previous studies showed the absence of small females $(<15 \mathrm{~mm})$ and large males $(>23 \mathrm{~mm})$ (Baladucci et al., 2006; Polidori et al., 2015). These observations led the authors to hypothesize that sequential hermaphrodism might characterize this species, with protandrous (from male to female) sex reversal process occurring between $18 \mathrm{~mm}$ and $20 \mathrm{~mm}$ SH (Baladucci et al., 2006; Polidori et al., 2015). By collecting individuals of various sizes and recording their sex, we cast doubt on the existence of this life history trait. We also model the sexual development process of males and females to determine the size at which individuals reach maturity. Histological analyses performed on different size classes for both sexes allowed us to describe the reproductive cycle of the species, estimate the size at first sexual maturity for male and female and provide evidence for gonochorism in this species.

\section{Materials and methods}

\subsection{Study area and fishing surveys}

Fisherman collected specimens of Tritia mutabilis in the Grau du Roi area of the Gulf of Lion in the Western Mediterranean Sea (Fig. 1) from March 2019 to March 2020. Specimens were caught with basket traps equipped with a finer mesh size $(4 \mathrm{~mm})$ than those traditionally operated by local fishermen $(10 \mathrm{~mm})$, in order to collect individuals with the broadest possible size range. Basket traps consist of a steel frame forming a truncated cone and covered with a cylindrical panel of netting suspended from either the smaller hoop (smaller base) or the larger hoop (the larger base) and tied underneath. The entrance of the trap is through the smaller base. A total of five basket traps baited with dead fish were used in each monthly fishing survey.

\subsection{Biology of the species and gonad histology}

As in most prosobranch gastropods described to date, the gonads of T. mutabilis (Fig. 2a) are located at the apex of the

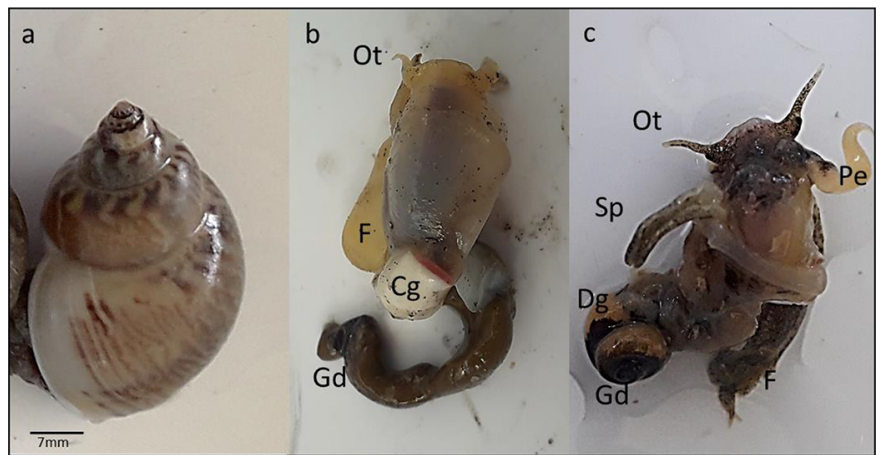

Fig. 2. T. mutabilis. (a) Whole specimen with its shell. (b) Anatomical details of a female. (c) Anatomical details of a male. Cg Capsule gland, Dg Digestive gland, F Foot, Gd Gonad, Ot Ocular tentacle, Pe Penis, Sp Siphon.

shell spiral and are at the edge of the hepatopancreas or the digestive gland (Dg, Fig. 2c). While the presence of the capsule gland in large female is clearly visible (Fig. 2b) and can be considered as gender identification criterion, each individual was sexually identified on the basis of the presence or absence of the penis in the right front part of the animal, behind the tentacle (Fig. 2c), as previously described (Polidori et al., 2015).

For histological examination, twenty individuals were selected each month over one year, for total of 240 specimens. No individuals smaller than $10 \mathrm{~mm}$ were ever collected in the baskets. We arbitrarily defined five size classes [10-15], [15-20], [20-25], [25-30], [30,35]. Once collected, T. mutabilis were cold anaesthetized for five minutes in the freezer and then measured for shell height (to the nearest $0.1 \mathrm{~mm}$ ) using a digital caliper (S_Cal EVO Sylvac IP67). The shell of each individual was then broken with a notched wrench and the entire soft part was extracted. Gonads were separately fixed (Formaldehyde 4\%, buffered Ph6.9, SigmaAldrich) for one week. The samples were then rinsed three times with $70 \%$ alcohol for 24 hours and sent to the Montpellier Experimental Histology Network (RHEM) for further processing. Gonads were dehydrated in a graded ethanol series, infiltrated and embedded in paraffin wax. Transversal sections ( $3 \mu \mathrm{m}$ thick) were cut from each gonad and stained with haematoxylin-eosin-safran (HES). For each gonad, 4 sections were mounted and examined under a light microscope (Nanozoomer Hamamatsu) using magnifications from $10 \times$ to $40 \times$.

\subsection{Sex-ratio and size at first maturity}

\subsubsection{Sex-ratio sampling}

For sex-ratio analysis we measured and sexed 428 randomly selected individuals in the fishing catches during the breeding period (March to May).

\subsubsection{Maturity stages}

To determine the size at sexual maturity in males and females, we focused on the presence of mature sex cells (late vitellogenic oocytes and spermatozoa) in the histological 
sections, as well as evidence of mating, visible in the histological sections by the presence of voids in the lumen of the seminiferous tubes and follicles.

To determinate size at first maturity, females were considered mature only when most oocytes were at the vitellogenic stage, with the germinal vesicle at the periphery of the oocyte. The numbers and shell height of immature and mature individuals were recorded to determine the size at maturity. Since we detected large immature females (some restarting oogenesis) after the breeding period, we only considered a subsample $(n=20)$ that was collected during the first process of maturation to estimate the size at maturity.

Males were considered mature only when the presence of sperm was detected. As for females, a subsample $(n=20)$ was collected during breeding period to estimate the size at first maturity.

\subsection{Reproductive cycle}

\subsubsection{Female}

Oocytes were counted and measured at different stages to describe the gonad development of females, the number of cells for each stage was counted in an area of $0.15 \mathrm{~mm}^{2}$ randomly chosen within each slide and a total of five different females were analyzed in each size class. Based on our histological observations and from previously published histological analyses of a related species, Buccinanops globulosus (Avaca et al., 2015), four distinct stages were considered (Fig. 3): Oogonia stage: oogonias are attached to the wall of the follicle and characterized by their low vacuolated ooplasm and the presence of two nucleoli (Fig. 3a). Previtellogenic stage: distinguished by an increase in vacuolated ooplasm, the germinal vesicle clearly visible and the presence of a single nucleolus (Fig. 3b). Secondary growth stage: oocytes are easily recognizable by the presence of yolk granules and a high increase in cytoplasmic volume (Fig. 3c). Vitellogenic stage: oocytes, with an average size of $500 \mu \mathrm{m}$, are characterized by a very large ooplasm volume, filled with vitellogenic granules and yolk droplets. Migration of the germinal vesicle to the oocyte periphery indicates extrusion of second polar body from egg nucleus, and the eggs are considered fertilizable at this stage (Fig.3d). The average number of oogonia, previtellogenic oocytes and vitellogenic oocytes was determined for each size class.

Finally, we performed oocyte measurements as an index of development. The major axis of the five largest oocytes in the subsample $\left(0.15 \mathrm{~mm}^{2}\right)$ was measured, giving a total of 25 oocyte major axes per size-class.

\subsubsection{Male}

The different stages of spermatogenesis were also identified in the various mal histological samples. Four stages were clearly distinguishable in the different individuals, although we present all of them in a single mature individual (Fig. 3e). Spermatogonia stage (Spg): cells are attached to the wall of seminiferous tube. They are diploid cells in mitotic proliferation. They have a slightly cubic appearance. Spermatocyte stage (Spc): These are meiotically dividing cells. They are rounder and larger than spermatogonia and

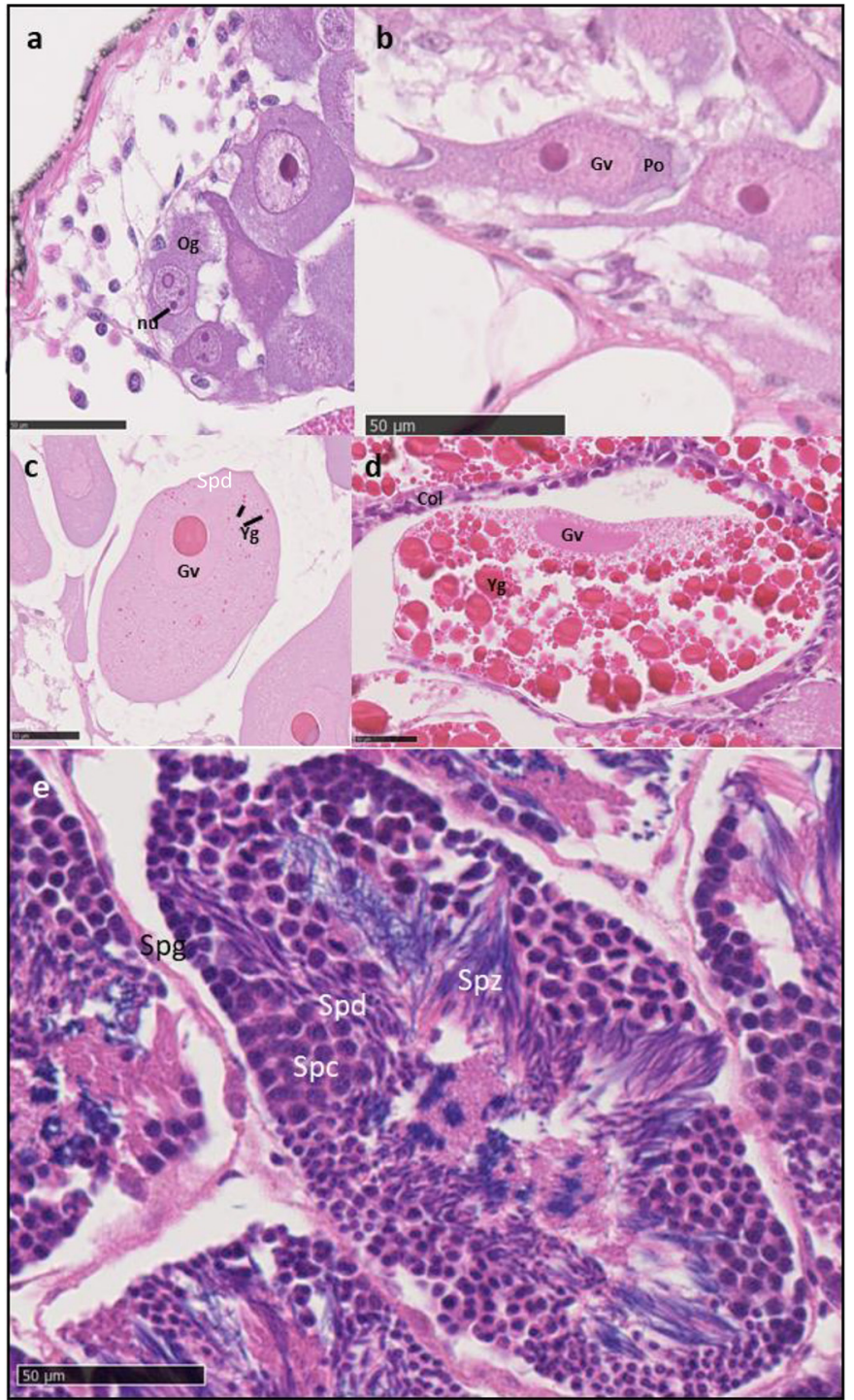

Fig. 3. Light microscopy of gametogenesis in $T$. mutabilis. a) Oogonia $(\mathrm{Og})$, attached to the follicle wall with the presence of two nucleoli (nu) b) Primary growth oocytes with increase of germinal vacuole $(\mathrm{Gv})$ and presence of a single nucleolus c) Secondary growth oocyte, cytoplasmic volume expansion and yolk granule (Yg) accumulation d) Vitellogenic oocyte. Germinal vesicle migration $(\mathrm{Gv})$ to the periphery of the oocyte. Accumulation and increase of yolk granules (Yg). e) Detail of seminal tube on mature male. Observation of the different stages of spermatogenesis. Spc Spermatocyte Spd Spermatid Spg Spermatogonia Spz Spermatozoa. Scale bars $=50 \mu \mathrm{m}$. Scale bars $=50 \mu \mathrm{m}$.

chromatin decondensation can be observed by the clearer appearance of the nucleus. Spermatid stage (Spd): These differentiated haploid cells have begun the process of cell elongation. Spermatozoa stage (Spz): These are mature cells, totally differentiated, highly recognizable by the long flagellum oriented towards the lumen, ready for being released into the vas deferens. 


\subsection{Data treatment and statistical analysis}

We estimated the normality of the size distribution of both males and females using a Shapiro-Wilk's test. As the data distributions were not normal, we then used a non-parametric Wilcoxon test to compare males and females. Sex-ratio ( $\mathrm{n}$ males/ $\mathrm{n}$ total) differences between months were estimated using a binomial model. To estimate the size at which a randomly chosen specimen has a $50 \%$ chance of being mature $\left(\mathrm{L}_{50}\right)$, we used the R package "sizeMat" (Torrejon-Magallanes, 2020 ) and the function "gonad_mature" with a Bayes logistic regression and 10000 iterations. Finally, the correlation between the number and size of oocytes was assessed using a linear model. All statistical analyses were performed with $\mathrm{R}$ (3.3.0).

\section{Results}

\subsection{Shell length frequency distribution at spawning period}

A total of 428 individuals were measured and their sex determined macroscopically (200 females and 228 males). While our basket was designed to trap all size range of gastropods, it captured only individuals from 15 to $36 \mathrm{~mm}$ (15.5-32.4 mm males; $16-35.9 \mathrm{~mm}$ females) during the breeding period. Overall, the mean size of females was greater than that of males $(30 \pm 3.7$ versus $24 \mathrm{~mm} \pm 2.7$; $\mathrm{W}=5334.5, p$-value $<2.2 \mathrm{e}-16)$. The sex-ratio did not significantly differ over the 3 months considered and averaged $53 \%$ of males.

\subsection{Gonad development stages}

\subsubsection{Undifferentiated gonads}

We considered undifferentiated cells as oogonia or spermatogonia according to the phenotypic sex. Oogonias were observed in females as small as $10 \mathrm{~mm}$, while spermatogonia were observed for males from $13 \mathrm{~mm}$ (Fig. 4 a, e).

\subsubsection{Histological sex differentiation}

Sex-specific features were already observed at the histological level for both males and females of $14 \mathrm{~mm}$, with early previtellogenic oocytes (Fig. 4b) and a cystic organization for male spermatogonia with sparse connective tissue (Fig. 4e, f). Histological analyses of 14, 16- and 18-mm specimens confirmed the presence of previtellogenic oocytes (Fig. 4b-d). No degenerating spermatozoa were observed in any section of female gonadal tissues. Spermatogonia and spermatocytes were observed for males smaller than $17 \mathrm{~mm}$ (Fig. 4f, g). For larger males, we observed spermatids, with probably few spermatozoa (Fig. 4h).

\subsubsection{Females}

No mature oocytes were observed for animals smaller than $24 \mathrm{~mm}$ (Fig. 5a). A large quantity of mature oocytes was observed for larger females (Fig. 5c). Between 24 and $25 \mathrm{~mm}$, not all females were fully mature as some had mainly developing oocytes (Fig. 5b, d). Between 25 and $30 \mathrm{~mm}$, most females had mature vitellogenic oocytes and were, therefore, considered sexually mature (Fig. 5e, f). Our model showed that the $\mathrm{L}_{50}$ was at $24.4 \mathrm{~mm}\left(R^{2}=0.65\right)$ (Fig. 6a). Lumens were also observed in the follicles of specimens between 28 and $29 \mathrm{~mm}$, most probably indicating that eggs had been expelled (Fig. 5g, h). Concurrently with the oocyte development process, a new batch of growing oocytes was found on the near the follicular wall (Fig. 5h). Specimens larger than $29 \mathrm{~mm}$ had two histological profiles, with either mature vitellogenic oocytes (caught during the breeding period) or developing oocytes as indicators of second development cycle (Fig. 5i,j). Those with developing oocytes were all caught between September and November. Proportion of cells at different stages of development for each size class was well in line with the histological description and revealed a change in the predominant cell type as the shell size increased (Fig. 7). From $25 \mathrm{~mm}$, as predicted by the model, there was a clear switch in the proportion of mature cells with the appearance of secondary growth oocyte and mature vitellogenic oocyte. There was also a strong correlation between mean oocyte cytoplasmic oocyte volume and shell height $\left(R^{2}=0.73 ; p<\right.$ 0.01 ; rho value $=0.83$ ).

\subsubsection{Males}

For males between 18 and $19 \mathrm{~mm}$, the testes became dense and differentiating cells occupied the seminal tube. All stages were represented. Spermatogonia (presumably type A) were on the wall of the seminal tube in active mitosis. Spermatogonia at the metaphase stage, with chromosome alignment along the equatorial plate were clearly distinguished, as in a $19.4 \mathrm{~mm}$ specimen (Fig. 8a). Spermatocytes and spermatids were also visible. Mature spermatozoa can be detected in the lumen of the seminal tube (Fig. 8a). From $23 \mathrm{~mm}$, there is a void in the lumen of the tube indicating sperm release into the vas deferens (Fig. 8e, g). The scattered appearance of the gonads in overall view of the section showed that all the seminiferous tubes had been emptied (Fig. 8d, f). Our model revealed that the $\mathrm{L}_{50}$ was $17.5 \mathrm{~mm}\left(R^{2}\right.$ of 0.9) (Fig. 6b).

\section{Discussion}

Our study provided new insights on the reproductive biology of Tritia mutabilis. A thorough histological analysis revealed that the species is likely gonochoristic. Most prosobranchs are gonochoristic and have internal fertilization. But the lack of studies on the reproductive biology of T. mutabilis and of Nassaridae in general, stimulated our research. Only a few studies focused on T. mutabilis (Crisp, 1978; Cespuglio et al., 1999; Baladucci et al., 2006; Piccinetti and Piccinetti-Manfrin, 1998; Salvato et al., 2001; Plessi et al., 2001; Solustri et al., 2002; Polidori et al., 2015; Caprioli et al., 2018), and protandry has been proposed only recently, with a sex change possibly occurring between 18 and $20 \mathrm{~mm}$ (Polidori et al., 2015). Our finding contradicts this view, since i) male and female gonads were never found simultaneously in any of the samples investigated and ii) small $(14 \mathrm{~mm})$ females and iii) large males (reaching $27 \mathrm{~mm}$ ) were found, contradicting the hypothesis of a possible protandrous sex-change. In addition, the sex ratio was always balanced 


\section{Females}

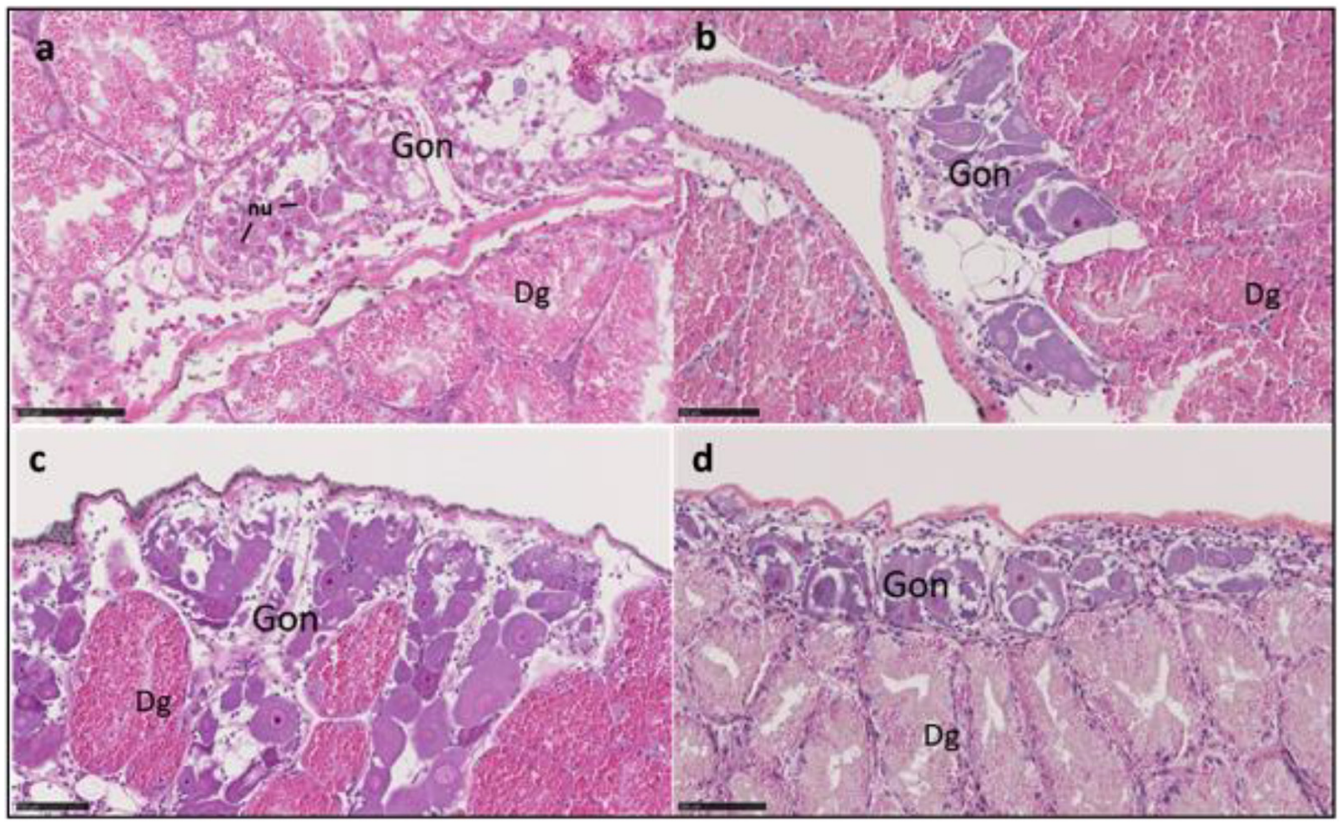

Males

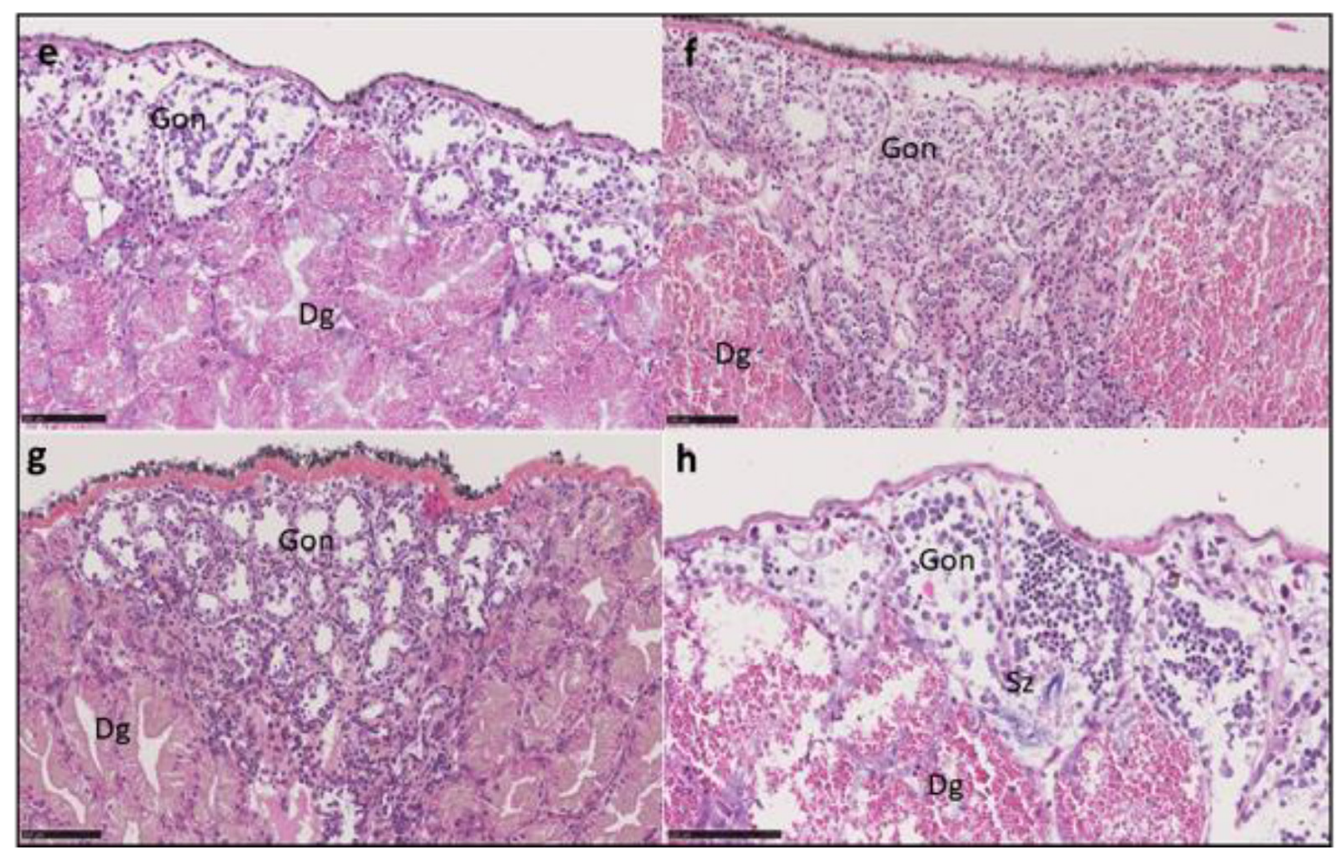

Fig. 4. T. mutabilis. Histological sections of the gonads of small $(\leq 20 \mathrm{~mm})$ male and female specimens. (a to d): female with increasing shell length (a $10 \mathrm{~mm}$, b $14 \mathrm{~mm}$, c $16 \mathrm{~mm}, \mathrm{~d} 18 \mathrm{~mm}$ ) (e to h), male with increasing shell length (e $13 \mathrm{~mm}, \mathrm{f} 14 \mathrm{~mm}, \mathrm{~g} 16 \mathrm{~mm}, \mathrm{~h} 17 \mathrm{~mm}$ ). Dg Digestive gland, Gon Gonads. nu nucleoli (two or three nucleoli are visible in (a) a $10 \mathrm{~mm}$ female), Sz Mature Spermatozoa. Scale bars $=100 \mu \mathrm{m}$.

during the breeding period. Finally, our study allowed providing mean size at first maturity for males $(17.5 \mathrm{~mm})$ and females $(24.4 \mathrm{~mm})$.

Our result on sex-ratio contrast with those obtained from Italian's studies. This contrasted pattern could well be due to the differential proportion of small individuals $(<12 \mathrm{~mm})$ that are overrepresented in Italian samples and from which penis identification is highly complicated at the macroscopic level. Interestingly, the difference in range size is also noticeable for large individuals that are more represented in French catches, 


\section{Females}

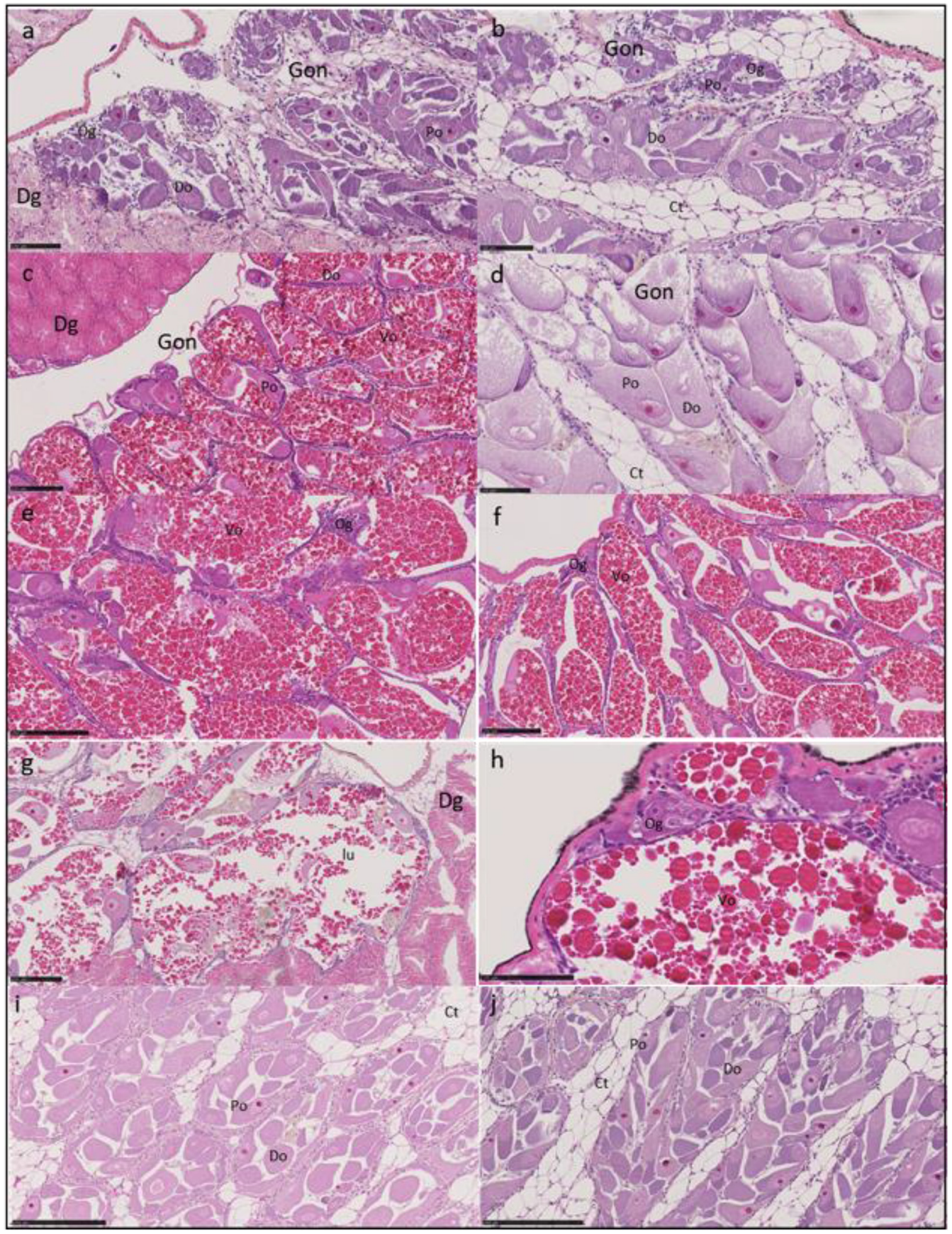

Fig. 5. T. mutabilis. Histological sections of the gonads of females larger than $20 \mathrm{~mm} \mathrm{SH}$. (a $20.5 \mathrm{~mm} \mathrm{SH}$, b and c $24 \mathrm{~mm}$, d $25 \mathrm{~mm}$, e $26.7 \mathrm{~mm}$, f $28.2 \mathrm{~mm}$, g $28.9 \mathrm{~mm}$, h $29.4 \mathrm{~mm}$, i $31 \mathrm{~mm}$, j $33.5 \mathrm{~mm}$.) Ct connective tissue, Dg Digestive gland, Do Developing oocite, Gon Gonade, lu lumen; Og Oogonia, Po pre-vitellogenic oocite, Vo vitellogenic oocite. Scale bars= $100 \mu \mathrm{m}(\mathrm{a}, \mathrm{b}, \mathrm{d}, \mathrm{h}) ; 250 \mu \mathrm{m}(\mathrm{c}, \mathrm{e}, \mathrm{f}, \mathrm{g}, \mathrm{i}, \mathrm{j})$.

so that populations differ in average size. We could thus hypothesis that difference in biotope between the Italian and the French coasts drive this whole pattern.

Regarding reproduction, we found that some large females $(>29 \mathrm{~mm})$ were still immature and that oogenesis had re-started for some of them between October and November. This suggests that either another reproductive period in late autumn exist or that individuals are able to reproduce again the next year between March and May. Results from previous studies performed on two phylogenetically close species of Nassaridae (Nassarius reticulatus and Buccinanops globulosus) would argue for the latter hypothesis, since spawning occurs between spring and early summer (Avaca et al., 2015; Barroso et al., 1998, Fretter and Graham, 1984). The large immature females we sampled were captured in the fall, which is consistent with observations on $N$. reticulatus and 
a)

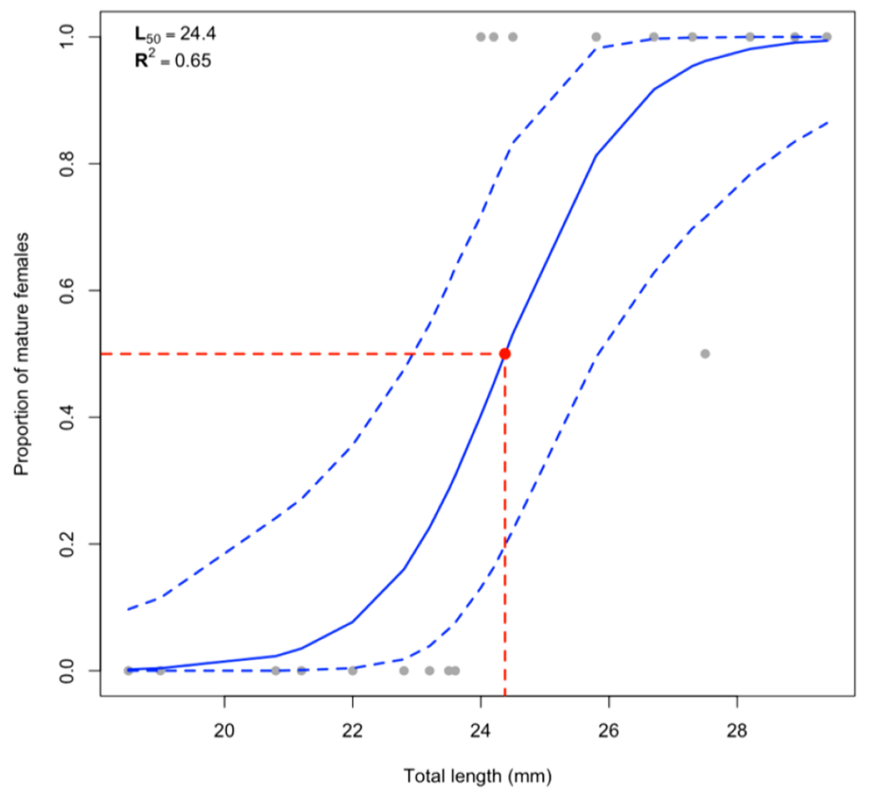

b)

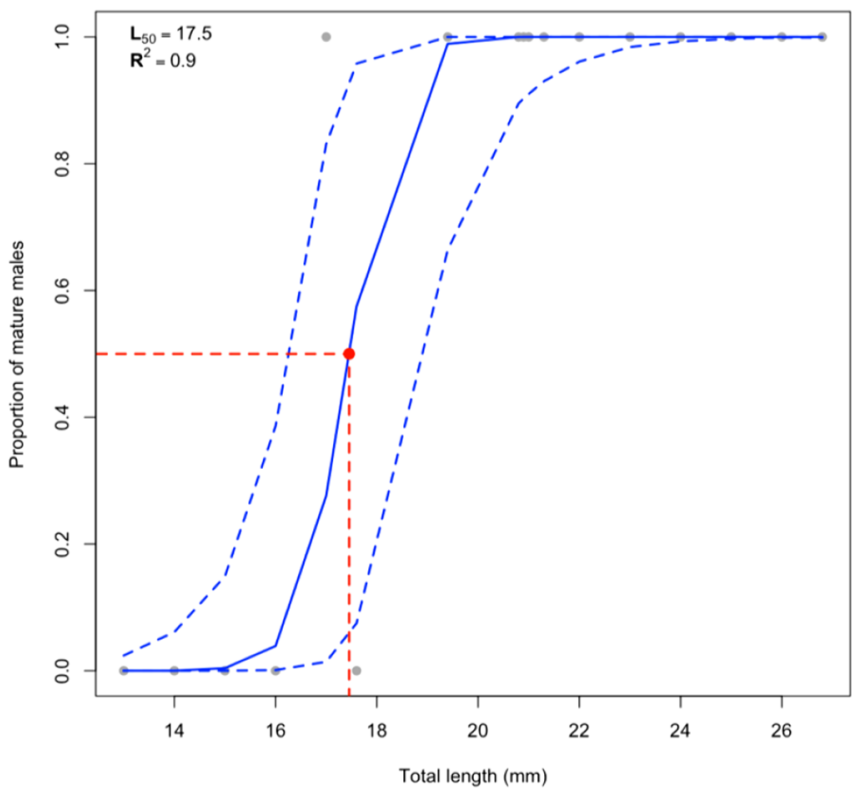

Fig. 6. The size at sexual maturity for a) Females and b) Males where the $\mathrm{L}_{50}$ (dashed red line) represents the length at which a randomly chosen specimen has a $50 \%$ chance of being mature. The fitted values for the logit regression (with the $\mathrm{R}^{2}$ value) and confidence intervals $(95 \%)$ are represented by solid and dashed lines respectively.

\section{Average proportion of different cell types by size class}

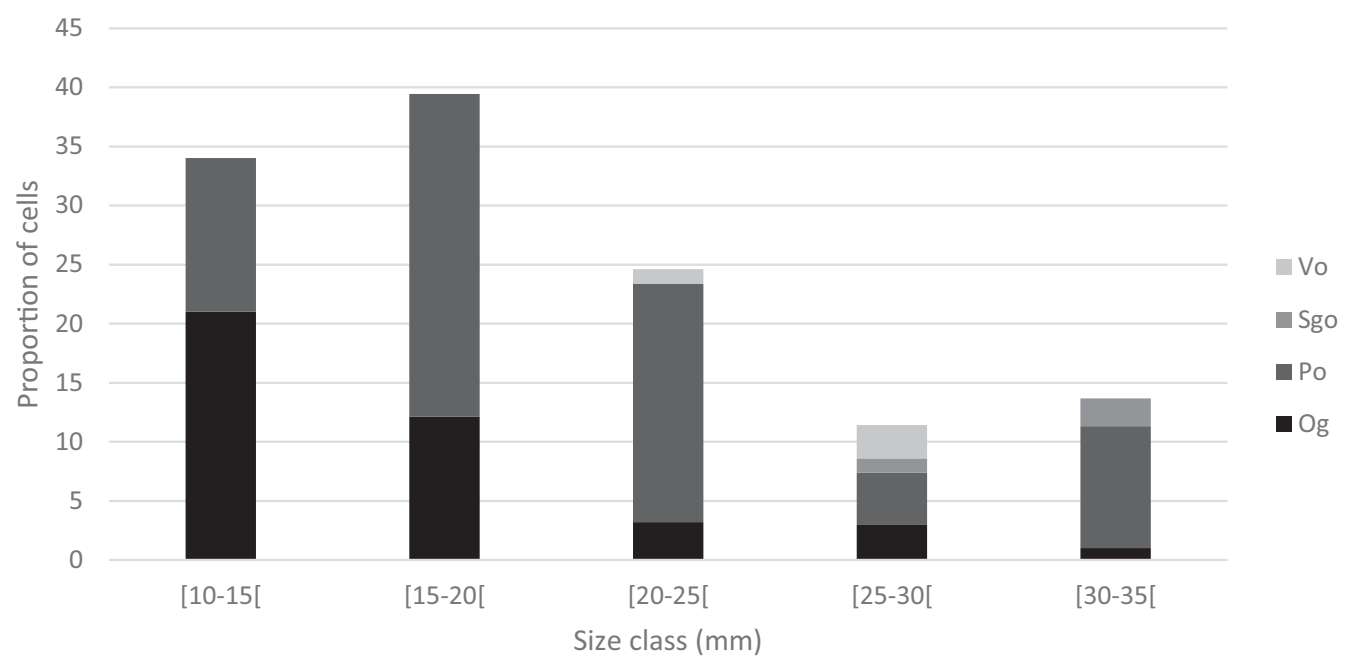

Fig. 7. Cells proportion for different development stages as a function of shell height in females. Og Ovogonia; Po Pre-vitellogenic oocyte; Sgo Secondary growth oocyte; Vo vitellogenic oocyte.

B. globulosus. Finally, spurious observations of veliger capsules by fisherman were always made in spring, confirming our histological-based conclusion and supporting the hypothesis of only one breeding season per year in this species.

For the process of sex differentiation, stem cell multiplication already occurred in specimens smaller than $14 \mathrm{~mm}$. However, our small number of samples that were between 6 and $14 \mathrm{~mm}$ did not allow us to identify, with certainty, the exact size at which histological sex differentiation starts. As previously pinpointed, the lack of small individuals in traps could be due to the fact that young individuals likely forage on different resources than older (and larger) individuals, so that the bait used did not attract small individuals.

Our modeling approach allowed to determine the size at first maturity for both sexes. Those data are highly relevant for reassessing the implementation basis for sustainable 


\section{Males}

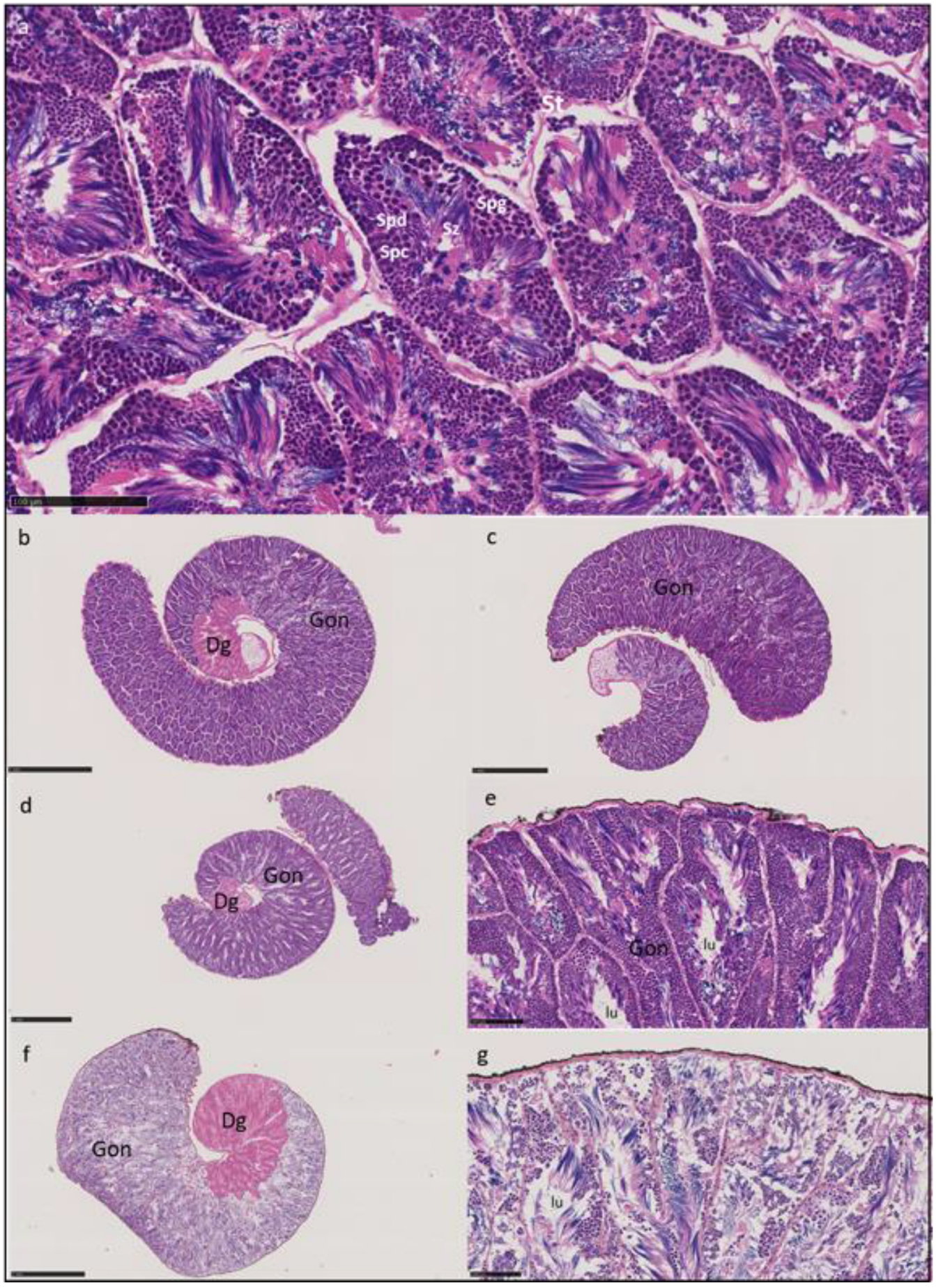

Fig. 8. T. mutabilis. Histological section of the gonads of males larger than $19 \mathrm{~mm} \mathrm{SH}$. (a $19.4 \mathrm{~mm}$, b 20.8 , c $21.5 \mathrm{~mm}$, d $23 \mathrm{~mm}$, e $23 \mathrm{~mm}$, f $25.5 \mathrm{~mm}$, g $25.5 \mathrm{~mm}$.) Scale bars $=100 \mu \mathrm{m}$ (a, e, g), $1 \mathrm{~mm}$ (b, c, d, f).

management plans of the resource. Indeed, the currently used management plan in Italy recommends a minimum capture size of $20 \mathrm{~mm}$. If populations in Italia are comparable to those of the present study, then females that did not reproduce are currently targeted by fishermen and this could be a reason why the resource is still declining despite efforts and measures to protect it. However, a previous study conducted in the Adriatic Sea in spring reported an average size of Tritia mutabilis considerably lower (Solustri et al., 2002) to that of those caught in the Gulf of Lion (this study). Indeed, males and females from the Solustri et al. (2002) study averaged 18.5 and $23.5 \mathrm{~mm}$, respectively, while they averaged 24 and $30 \mathrm{~mm}$ in 
the present study. We could thus not discard a potential strong effect of local conditions on size at first maturity, and a comparative study assessing mean individual size and timing of reproduction would be necessary to better depict and understand these differences. The population dynamics of many species of gastropods are influenced by human activities such as fishing or environmental pollution (Avaca et al., 2015). Studies of biotic conditions and anthropic pressures on the two fishing sectors could provide answers on the different average sizes and sizes at sexual maturity for both sexes observed between the T. mutabilis populations.

\section{Conclusion}

In this study, we provide more insights on the reproductive biology of $T$. mutabillis. Our observations contradict the previously established hypothesis that the species is protandrous, despite the clear sexual dimorphism where females are larger than males. The estimated sizes at sexual maturity provide crucial information for the implementation of a sustainable management plan. Hence, we believe that the present study will pave the way for future discussions with local fishermen to implement a sustainable management of the resource.

Acknowledgments. This study was supported by the European Maritime and Fisheries Fund (PEEXNAC project). We would like to thank the professional fishermen for their engagement in this study, as well as Tony Tebby for English correction and suggestions and Jean-François Holley, coordinator of the PEEXNAC project. We thank the "Réseau d'Histologie Expérimentale de Montpellier" - RHEM facility supported by SIRIC Montpellier Cancer (Grant INCa Inserm DGOS 12553), the European regional development foundation and the Occitanian region (FEDER-FSE 2014-2020 Languedoc Roussillon) for processing our animal tissues, histology technics and expertise.

\section{References}

Avaca MS, Martín P, Van der Molen S, Narvarte M. 2015. Comparative study of the female gametogenic cycle in three populations of Buccinanops globulosus (Caenogastropoda: Nassariidae) from Patagonia. Helgoland Mar Res 69: 87-99.

Baladucci GM, Omiccioli H, Giannattasio S, Minelli D, Collevecchio V, Vallisneri M, Sabelli B. 2006. Studio sulla biologia e distribuzione di Nassarius mutabilis (L., 1758) (Gastropoda,
Prosobranchia) nel compartimento marittimo di Pesaro per una corretta gestione della risorsa. Biol Mar Medit 13: 156-157.

Barroso CM, Moreira MH. 1998. Reproductive cycle of Nassarius reticulatus in the Ria de Aveiro, Portugal: implications for imposex studies. J Mar Biol Assoc UK 78: 1233-1246.

Caprioli R, Giansante C. 2018. Preliminary investigation on the use of artificial substrates to favor Tritia mutabilis (Linnaeus, 1758) spawning in Central Adriatic Sea: a possible contribution to stock maintenance. Acta Adriat 59: 141-148.

Cespuglio G, Piccinetti C, Longinelli A. 1999. Oxygen and carbon isotope profiles from Nassa mutabilis shells (Gastropoda): accretion rates and biological behaviour. Mar Biol 135: $627-634$.

Crisp M. 1978. Effects of feeding on the behaviour of Nassarius species (Gastropoda: Prosobranchia). J Mar Biol Assoc UK 58: 659-669.

Fabi G, Giannini S. 1983. Considerazioni sulla pesca della lumachina di mare Sphaeronassa mutabilis (L.) in Adriatica. Gazzettino della Pesca 30: 8-10.

Fisher W, Bauchot ML, Schneider M. 1987. Fiches FAO d'identification des espèces pour les besoins de la pêche. Méditerranée et Mer Noire. Zone de pêche 37. Vol. 1. FAO, Rome, 760 pp.

Fretter V, Graham A. 1984. The prosobranch molluscs of Britain and Denmark. Part 8. Neogastropoda. J Molluscan Stud 15: 435-556.

Grati F, Polidori P, Scarcella G, Fabi G. 2010. Estimation of basket trap selectivity for changeable nassa (Nassarius mutabilis) in the Adriatic Sea. Fish Res 101: 100-107.

Leiva GE, Castilla JC. 2002. A review of the world marine gastropod fishery: evolution of catches, management and the Chilean experience. Rev Fish Biol Fish 11: 283-300.

Piccinetti C, Piccinetti-Manfrin G. 1998. Considerazione per la gestione della pesca del lumachino, Nassarius mutabilis (Linnaeus, 1758). Biol Mar Medit 5: 355-361.

Plessi M, Bertelli D, Monzani A. 2001. Mercury and selenium content in selected seafood. J Food Compos Anal 14: 461-467.

Polidori P, Grati F, Bolognini L, Domenichetti F, Scarcella G, Fabi G. 2015. Towards a better management of Nassarius mutabilis (Linnaeus, 1758): biometric and biological integrative study. Acta Adriat 56: 233-44.

Salvato B, Cuomo V, Di Muro P, Beltramini M. 2001. Effects of environmental parameters on the oxygen consumption of four marine invertebrates: a comparative factorial study. Mar Biol 138: 659-668.

Solustri C, Fabi G, Magi M, Panfili M, Spagnolo A. 2002. Biometrics of Nassarius mutabilis (1.) (Gastropoda, Nassaridae) in the Central Adriatic Sea. Boll Malacol 4: 79-82.

Torrejon-Magallanes J. 2020. sizeMat: Estimate Size at Sexual Maturity. R package version 1.1.1. https://CRAN.R-project.org/ package $=$ sizeMat.

Cite this article as: Mallet A, Jouvenel J-Y, Broyon M, Pirot N, Geffroy B. 2021. Histology of Tritia mutabilis gonads: using reproductive biology to support sustainable fishery management. Aquat. Living Resour. 34: 6 